\title{
MODEL APLIKASI UML DALAM PELAKSANAAN KULIAH KERJA NYATA (KKN)
}

\author{
Sri Widaningsih \\ wsrik.bun79@gmail.com \\ Rayhan Rahmat Aziz Gamawanto \\ rayhanrahmatazizgamawanto.r18mi@plb.ac.id \\ Yudha Pratama \\ yudhapratama.r18mi@plb.ac.id \\ Rafly Yusrizal Amrie \\ raflyyusrizalamrie.r18mi@plb.ac.id \\ POLITEKNIK LP3I BANDUNG
}

\begin{abstract}
ABSTRAK
Kegiatan Kuliah Kerja Nyata (KKN) Tematik merupakan salah satu program di POLITEKNIK LP3I yang bertujuan untuk membangun kepekaan mahasiswa sebagai generasi penerus untuk mampu bersosialisasi dengan masyarakat, peka terhadap masalah yang terjadi dalam masyarakat dan mampu memberikan solusi atas permasalahan sesuai bidang keilmuan yang ditekuni dan keahlian yang dimiliki. KKN tahun 2020 merupakan KKN yang dilakukan di tengah terjadinya pandemi sehingga untuk membantu kelancaran kegiatan KKN tersebut diperlukan pengelolaan proses berbasis online. Tahapan metode penngabdian meliputi 6 tahapan utama, dimana proses utamanya adalah pelaksanaan fasilitas kkn berbasis online ini menuntut adanya sistem informasi yang berguna dalam menangani seluruh proses perencanaan dan pelaksanaan dan evaluasi proses $K K N$ mulai dari pendaftaran $K K N$, pembagian kelompok KKN, laporan KKN, fitur deteksi lokasi UMKM serta lokasi KKN tiap mahasiswa, tempat pelaksanaan KKN, mengetahui dosen pembimbing lapangan (DPL) dan sebagai sarana mempublikasikan informasi yang berhubungan dengan kegiatan KKN. Hasil dari rancang bangun ini adalah sebuah sistem informasi yang digunakan untuk pengelolaan kegiatan KKN. Sistem ini dirancang menggunakan pemodelan UML (Unified Modeling Language), sedangkan bahasa pemrograman yang digunakan adalah PHP dan database MySQL serta dibangun menggunakan framework Codeigniter. Hasil kegiatan pengabdian pada masyarakat ini adalah mampu mencetak generasi yang siap berkolaborasi dan membantu masyarakat dalam meningkatkan Indek Pembangunan Manusia (IPM).
\end{abstract}

Kata kunci: Aplikasi, KKN, Website.

\section{PENDAHULUAN}

Saat ini, kebutuhan akan informasi menjadi kebutuhan di berbagai bidang antara lain bidang pendidikan, budaya, pemerintah maupun masyarakat pada umumnya. Dalam bidang pendidikan terutama pendidikan tinggi keberadaan 
sistem informasi menjadi kebutuhan dasar yang senantiasa mendukung pelaksanaan tridharma pendidikan tinggi, baik itu dari unsur pendidikannya, penelitiannya maupun pengabdiannya.

Indonesia di awal tahun 2020 mendapat dampak dari salah satu kondisi terjangkitnya pandemi Covid-19 yang terjadi. Adanya pendemi tidak harus membuat kita sebagai pelaksana sistem pendidikan dalam hal ini pelaksana pendidikan tinggi menyerah dan pasrah dengan keadaan. Tridharma perguruan tinggi senantiasa harus dijalankan institusi dengan baik, walaupun pada prosesnya dilakukan dengan berbagai inovasi dan kreatifitas yang maksimal, sehingga kegiatan tridharma perguruan tinggi dapat dilaksanakan.

Pengabdian sebagai salah satu kegiatan tridharma perguruan tinggi yang harus dilaksanakan dalam setiap tahun ajarannya menuntut institusi Politeknik LP3I juga dapat melaksananya walaupun di tengah pandemik yang sedang terjadi. Sasaran utama pelaksanaan kegiatan KKN ini adalah seluruh dosen yang aktif di politeknik LP3I dan mahasiswa angkatan 2019. Kegiatan pengabdian yang dilakukan menyesuaikan dengan program pemerintah yaitu melalui kegiatan Kuliah Kerja Nyata (KKN) Tematik. Penyelenggaraan KKN Tematik ditujukan untuk menjangkau empat sasaran utama. Pertama, sebagai sarana pembelajaran bagi para mahasiswa (peserta KKN) untuk mengimplementasikan ilmu yang sudah didapatkan selama perkuliahan. Kedua, Perguruan tinggi dapat menjalin kerjasama dengan berbagai pihak dalam melaksanakan pembangunan dan pengembangan IPTEKS. Ketiga, Membantu memecahkan masalah di masyarakat. Keempat, meningkatkan Indeks Pembangunan Manusia (IPM).

Pelaksanaan kegiatan KKN di tahun 2020 ini menjadi KKN yang special yaitu pelaksanaan KKN harus dapat terlaksana di tengah pandemi Covid-19. Kondisi tersebut menuntut Lembaga Penelitian dan Pengabdian pada Masyarakat (LPPM) dan panitia pelaksana KKN Tematik 2020 harus mampu berinovasi dan berkreasi agar $\mathrm{KKN}$ Tematik 2020 masih bisa dilaksanakan secara maksimal. Proses pengelolaan KKN Tematik tahun 2020 ini berbeda dengan proses pengelolaan sebelumnya, Proses KKN kali ini mau tidak mau harus mampu membuat terobosan baru yaitu proses yang tidak mengharuskan para peserta berinteraksi secara langsung yaitu dengan cara daring atau online. $\mathrm{KKN}$ online dilakukan dengan tetap bisa menyimpan data sebagai bahan dokumentasi diantaranya registrasi peserta KKN, pembagian kelompok, laporan tiap kelompok, deteksi Lokasi UMKM dan sekolah terdekat, deteksi lokasi tiap peserta KKN, pembagian dosen pembimbing lapangan (DPL), sharing data dokumentasi proses pelaksanaan KKN di lapangan, dan membuat laporan akhir KKN Tematik.

Jawaban dari kebutuhan akan sarana KKN di era pandemik inilah LPPM beserta tim membuat suatu sistem informasi untuk mengakomodir kegiatan KKN Tematik tersebut melalui model aplikasi UML, sehingga proses KKN dapat terlaksana dengan baik tanpa adanya hambatan akan situasi dan kondisi yang terjadi dewasa ini. Kedepan mahasiswa dalam segala situasi dan kondisi yang ada dan masih bisa melakukan kegiatan KKN dalam rangka mencetak generasi yang siap berkolaborasi dan membantu masyarakat dalam meningkatkan Indek Pembangunan Manusia (IPM).

\section{METODOLOGI PELAKSANAAN}

Metode merupakan ssstem tindakan yang akan dilakukan ataupun urutan atau tahapan-tahapan yang perlu dalam menjalankan kegiatan pengabdianpengabdian pada masyarakat. Adapun tahapan yang ada dalam proses $\mathrm{KKN}$ ini adalah sebagai berikut:

1. Analisi situasi sebagai awal kegiatan untuk analisis situasi kondisi

2. Identifikasi masalah, merupakan analisis kerja sasaran dari permasalahan yang ada. 
3. Menentukan tujuan kerja secara spesifik.

4. Rencana pemecahan masalah, melalui proses identifikasi masalah terlebih dahulu kemudian dipecahkan untuk mencapai tujuan.

5. Pendekatan sosial; sebagai pendekatan terhadap masyarakat sasaran.

6. Pelaksanaan kegiatan, pelaksanaan kegiatan sesuai dengan proses perencanaan.

7. Evaluasi kegiatan dan hasil, hal ini dilaksanakan agar munculnya keyakinan akan kebenaran apapun yang ada hubungannya dengan perusahaannya.

Berikut bagan tahapan pelaksanaan $\mathrm{KKN}$ :

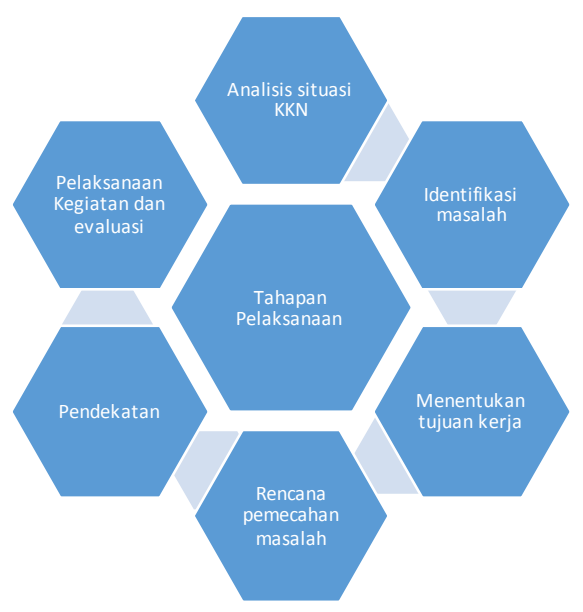

Gambar 1. Tahapan KKN.

Tahapan - tahapan yang akan dilakukan dalam implementasi model aplikasi UML ini meliputi :

1. Riset kendala dalam pelaksanaan kuliah kerja nyata $(\mathrm{KKN})$

2. Pembuatan sistem berbasis PHP dan Database MySQL

3. Pengujian sistem

4. Sosialisasi sistem

5. Implementasi sistem

6. Evaluasi sistem

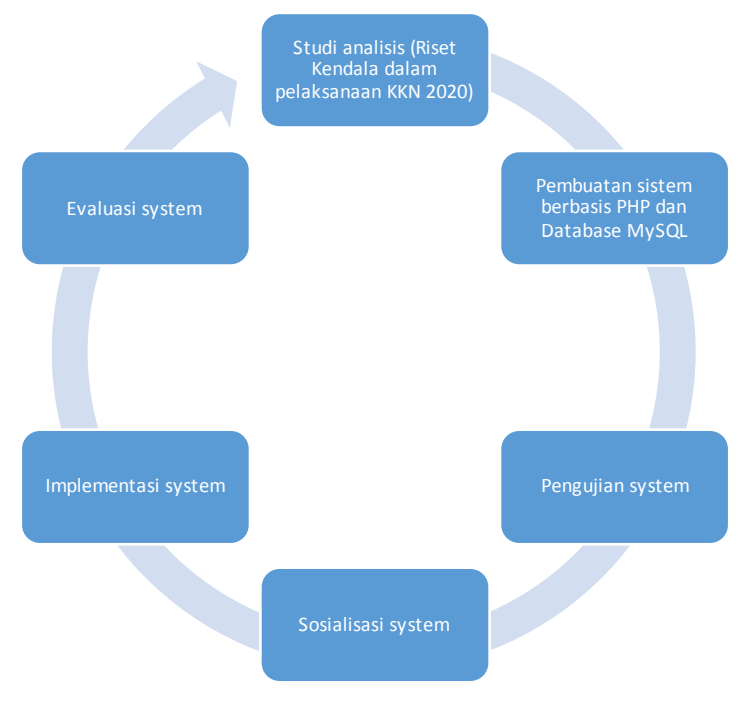

Gambar 2. Alur Pembuatan Aplikasi.

\section{HASIL DAN LUARAN}

Rencana pemecahan dari hasil identifikasi perlu dipecahkan melalui tahapan; mencari alternatif pemecahan masalah, dan memilih salah satu alternatifnya. Alternatif pemecahan masalah KKN di era pandemi ini adalah adanya sistem yang bisa membantu agar proses kegiatan dapat tetap berjalan tanpa harus berinteraksi langsung di lapangan, dan aplikasi UML menjadi salah satu alternatifnya agar proses dapat terselenggara dengan baik.

Pendekatan yang dihasilkan adalah dengan sistem aplikasi UML yang telah tim kembangkan, Sistem yang dihasilkan dalam menjawab kebutuhan sistem untuk proses KKN Tematik 2020 adalah dengan pembuatan sistem informasi KKN 2020 di Era Pandemi. Sasaran utama dikembangkannya sistem ini adalah untuk kebutuhan proses pelaksanaan KKN Tematik tahun 2020 di era pandemi yang mengharuskan proses KKN nya berupa daring dengan membatasi kegiatan tatap muka dilapangan. Walaupun pada prosesnya tetap masih ada kegiatan yang bersifat tatap muka yang dibatasi dan tetap 
memperhatikan Adaptasi Kebiasaan Baru (AKB) serta senantiasa menerapkan protokol kesehatan yang cukup ketat di lapangnya dengan bimbingan dan arahan dari masing-masing Dosen Pembimbing Lapangan (DPL)

Pelaksanaan aplikasi sistem informasi UML ini dirancang melalui 4 menu utama diantaranya:

1. Lokasi KKN, hal ini untuk mempermudah pihak terkait dalam membimbing, berkoordinasi dan mensupervisi proses pelaksanaan baik untuk pihak LPPM, panitia, DPL, tim pengawas atau tim lainnya yang memiliki kepentingan.

2. Kelompok KKN, menu ini memperlihatkan anggota kelompok dan siapa DPL yang bertugas membimbing dan mengarahkan kelompok tersebut.

3. Report KKN, menu ini memudahkan seluruh anggota dan DPL untuk mengakses informasi dan proses pelaporan kegiatan KKN, baik laporan harian, mingguan dan laporan akhir kegiatan.

4. About $\mathrm{Me}$, menu ini adalah untuk melihat profil dari masing-masing anggota kelompok dan DPL pembimbingnya, sehingga siapa saja yang bisa membuka akses ini akan tahu, siapa, apa kapasitas diri anggota kelompok, dan data lainnya yang dapat dijadikan sumber informasi dari peserta $\mathrm{KKN}$ tersebut.

Berikut gambar tampilan dari menu sistem informasi KKN Tematik 2020:

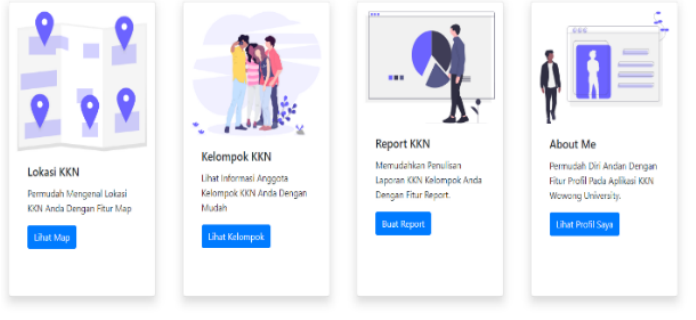

Gambar 3. Alur Pembuatan Aplikasi.
Pelaksanaan aplikasi tersebut seluruhnya sudah mencakup penetapan kegiatan yang dilakukan, rincian proses pelaksanaan kegiatan di masing-masing kelompok, memperjelas tempat pelaksanaan kegiatan dengan di dalamnya ada sistem google maps (untuk mendeteksi dimana kegiatan dilaksanakan), dan dapat melihat siapa saja yang terlibat dalam proses $\mathrm{KKN}$ tersebut, dimana masing-masing individu yang terlibat memiliki akun sendiri untuk bisa mereka akses dengan tingkat keamanan yang sudah dirancang kerahasiaannya. Sedangkan kegiatan evaluasi dilakukan untuk meyakini bahwa seluruh proses yang ada sudah berjalan dengan lancara dan baik sesuai dengan arahan dan tujuan kegiatan. Dan pada akhirnya evaluasi ini dilakukan agar adanya proses penyempurnaan dalam proses kegiatan $\mathrm{KKN}$ di masa yang akan datang.

Sistem aplikasi UML ini ke depan mampu memberi dampak positif terhadap proses pelaksanaan KKN apabila situasi dan kondisi tertentu seperti yang terjadi pada proses KKN di tahun 2020. Sistem aplikasi UML yang dirancang memang untuk membantu proses pelaksanaan kegiatan KKN yang sebelumnya harus senantiasa dilakukan melalui proses tatap muka, dengan adanya sistem ini kegiatan masih dapat dilaksanakan dengan baik sistem online. Dengan demikian apapun situasi dan kondisinya pelaksanaan KKN akan tetap bisa terlaksana dengan baik.

\section{Luaran}

Luarannya selain sistem ini adalah dengan dibuatnya buku panduan kegiatan KKN Tematik 2020 berbasis online yang didalamnya memuat seluruh aturan dan petunjuk teknis dari proses serta aturan pelaksanaan KKN Tematik 2020.

Selain itu, buku panduan ini dibuat untuk mempermudah akses sistem informasi KKN tematik ini. Dan terpenting adalah tautan sistem informasi/aplikasi UML ini terintegrasi dengan link LPPM dan Sistem Informasi Akademik (SIA) yang 
dikembangkan oleh institusi Politeknik LP3I.

\section{KESIMPULAN DAN SARAN}

Kesimpulan dari pengembangan model aplikasi UML dalam pelaksanaan KKN Tematik berbasis online tahun 2020, sebagain sarana proses pengabdian penulis adalah sebagai berikut:

1. Model aplikasi KKN dikembangkan untuk menjawab kebutuhan dalam proses pelakasanaan KKN Tematik berbasis online 2020.

2. Seluruh data yang diperlukan untuk kebutuhan KKN Tematik ini semua dapat tersimpan dengan baik dalam sistem yang terintegrasi dengan baik, dengan tautan dari portal LPPM.

3. Pengunaan sistem aplikasi ini kedepan dapat lebih membantu proses pengabdaain.

4. Seluruh menu mampu membantu peserta dan unsur terkait lainnya untuk mendapat informasi terkait kegiatan KKN Tematik 2020. Dan yang paling utama seluruh bagian dari menu mampu membantu proses kegiatan KKN Tematik berbasis online tahun 2020 sehingga seluruh proses KKN Tematik ini masih bisa terlaksana dengan baik.

\section{DAFTAR PUSTAKA}

Dharwiyanti, S. (2007). Pengantar Unified Modeling Language (UML). Bandung: Ilmu Komputer.

Fathansyah (2007). Basis Data. Bandung: Informatika.

Gata, W dan Gata, G. (2013). Sukses Membangun Aplikasi Penjualan dengan Java. Jakarta: Elex Media Komputindo.

Harianto. (2003). Konsep dan Perancangan Database. Yogyakarta: Andi Offset.

Jogiyanto, H.M. (2005). Analisis dan Desain Sistem Informasi. Yogyakarta: Andi Offset.
Kadir, A. (2002). Dasar Pemrograman Web Dinamis Menggunakan. PHP. Yogyakarta: Andi.

Kadir, A. (2008). Belajar Database Menggunakan MySQL Yogyakarta: Andi.

Mubarak, A. (2019). Rancang Bangun Aplikasi Web Sekolah Menggunakan UML dan PHP berorientasi Objek. JIKO

Pohan, HI. (2005). Analisa dan Perancangan Sistem Informasi Manajemen. Bandung: Institut Teknologi Bandung.

Pressman, R.S. (2010). Software Engineering: A Practicioner's Approach. (7th Edition). New York: McGraw-Hill Inc

Rosa, A.S, Shalahuddin, M. (2013). Rekayasa Perangkat Lunak Terstruktur dan Berorientasi Objek. Bandung: Informatika.

Sidik, B dan Pohan. H.I. (2007). Pemrograman WEB dengan HTML. Bandung: Informatika.

Simarmata, J. (2010). Rekayasa Perangkat Lunak. Yogyakarta: CV Andi Offset.

Sumiyana. (2002). Konsep dan Tuntunan Praktis Basis Data. Yogyakarta: Andi Offset.

Sutabri, T. (2012). Konsep Sistem Informasi. Yogyakarta: CV. Andi Offset.

Tim LPPM. (2020). Pedoman KKN di Era Pandemi. Bandung: Politeknik LP3I. 